\title{
The Night Sky
}

\section{Tamara Barrett}

THE NIGHT SKY is made strange by the blood-red moon penetrating through the darkness, leaving everything it touches looking awkward and unfamiliar.

As I walk down the laneway through the shadows I catch a glimpse of someone walking towards me. It's the old lady who lives in the apartment below mine, her small arthritic dog sniffing slowly along the cobblestones behind her.

What if I killed the old lady right here? Wrapped my fingers firmly around her throat until she silently choked her last breath. Squeezing so tight I might actually snap her brittle neck before she even had time to suffocate. Leaving her body for the neighbours, who would only discover her when she began to decompose - the rotting smell finding its way through the cracks in their houses.

Her death would be a mystery. Talk of the neighbourhood, until something worse happened the next month. No one would ever know I had killed her. Her dog might bark, but I doubt anyone would notice - its voice almost gone - used up over the years barking at birds and trees rustling in the wind.

Her death would be insignificant. She's bound to go soon, so fragile and worn, just waiting for the reaper to whisk her away to worlds unknown. I think about my grandfather lying in his hospital bed, weak and helpless - a shell of his former self - barely surviving as the cancer eats away at his body.

Her death would be an offering to the angel of darkness, in exchange for my grandfather's. He can have whatever life she has left - a trade of sorts. If only to postpone his death a little, just enough so he can wake from his slumber, so that I can have the chance to say goodbye.

I realise I've stopped walking and I am staring at her as she moves closer. Adrenalin is pumping through my body, tingling its way from 
my head to my fingertips. She has almost reached the large drain in the middle of the lane. If I moved fast enough I could bash her over the head with a rock, then lift the grate and throw her in - if she didn't die from the blow, the cold would surely kill her.

The old lady beckons her dog to hurry up then lifts her head as she notices me.

This is the moment - it's here - take it.

'Alright Mrs Michaels? How are your veggies coping with this weather?'

'I'm good thank you Samuel, but the tomatoes are struggling. Say hello to your mother for me next time she calls.'

'Yes, Ma'am. I will.'

I nod my head as Mrs Michaels passes then I continue walking. She begins to speak again, her words slightly muffled as we walk in opposite directions.

'Oh and give your grandfather my best wishes.'

I stop walking again and turn slowly towards her, yanking loose a small panel of wood from the fence beside me. 